\title{
ASPEK-ASPEK PENDIDIKAN DALAM SALAT
}

\author{
Oleh: Salamattang*
}

\begin{abstract}
ABSRTACT: There are a number of calls for prayer in the Qur'an and Prophetic Tradition. It is the second pillar of Islam and is of great importance to judge the level of belief of a Muslim. Each aspect of prayer contributes some values of education to develop good character in the society. Some researchers and personal experiences have provided evidence of this. This study will discus some aspects of education derived from the movement of prayer in line with the Qur'an and Prophetic Tradition as well as the research findings and personal experience of others.
\end{abstract}

KEYWORDS: education, prayer, Alquran and Prophetic Tradition.

HADIS-HADIS Nabi telah termaktub dalam berbagai kitab hadis dan telah beredar di kalangan masyarakat luas, khususnya umat Islam. Dalam kitab-kitab hadis tersebut ditemukan banyak tema yang membicarakan tentang pendidikan. Fakta ini juga membuktikan bahwa hadis-hadis tentang pendidikan yang terdapat dalam kitab-kitab hadis sangat banyak jumlahnya. Bahkan, hadis-hadis tentang pendidikan memiliki pembahasan yang sangat variatif dalam kitab-kitab syarah hadis.

Kaitannya dengan tema pendidikan dan salat, maka hadis-hadis

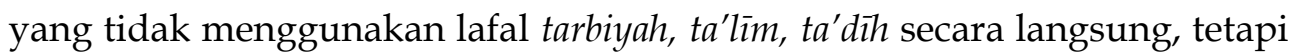
hadis tersebut memiliki kaitan dengan urgensi pendidikan, dapat pula dikategorikan sebagai hadis pendidikan sebagai hadis pendidikan secara tematik. Misalnya saja, hadis tentang perintah untuk mendidik anak menjalankan atau melaksanakan salat lima waktu sejak umur tujuh tahun.

Banyaknya hadis-hadis Nabi Saw. yang terkait dengan pendidikan, hal itu merupakan hal yang wajar, karena harus diakui bahwa dalam sejarah Nabi Saw, diketahui beliau dalam setiap harinya senantiasa mendidik dan mengajar sahabat-sahabatnya. Sistem pendidikan dan pengajaran tersebut disampaikannya secara formal melalui forum mejelis ilmu, di samping itu beliau juga menyampaikan pengajaran secara non formal melaui

*Kandidat Doktor dalam bidang Pendidikan dan Keguruan di PPs UIN Alauddin ini adalah dosen tetap pada Fakultas Tarbiyah dan Keguruan dan pengampu mata kuliah pendidikan Bahasa Arab. 
pertemuan-pertemuan yang tidak resmi, khususnya mengajar para sahabat salat lima waktu sebagai miniatur kehidupan duniawi.

Dapatlah dipahami bahwa Nabi Saw selama hidupnya, telah memberi perhatian khusus terhadap masalah pendidikan. Responsi dan stimulus Nabi Saw. terhadap masalah pendidikan ini, paling tidak dapat dilihat dari hadis-hadisnya. Karena itu, dapat dikatakan bahwa ajaran Islamlah yang amat peduli terhadap masalah pendidikan.

Kenyataan di atas, berimplikasi terhadap pentingnya penelitian hadis-hadis tentang pendidikan yang kemudian dihubungkan dengan salat yakni aspek-aspek pendidikan dalam salat. Lebih penting lagi bila hadis-hadis tersebut dielaborasi dengan metode tematik (syarh al-mawadh $\bar{u}-i$ ) dengan tetap memperhatikan kegiatan-kegiatan lainnya, seperti kegiatan fakhrij alhadits, naqd al-hadits, dan figh al-hadits.

\section{PERMASALAHAN}

Berangkat dari latar belakang di atas, maka penulis merumuskan pokok permasalahnnya yakni masalah aspek-aspek pendidikan dalam salat dengan batasan-batasannya sebagai berikut:

1. Bagaimana konsep fitrah dalam dunia pendidikan?

2. Bagaimana pendidikan salat bagi anak sejak umur tujuh tahun?

3. Analisis aspek-aspek pendidikan dalam salat?

\section{PENGERTIAN}

\section{Pendidikan}

Kata pendidikan ${ }^{1}$ pada awalnya berasal dari bahasa Yunani yakni paedagogie yang terdiri atas dua kata, paes dan ago. Kata paes berarti anak dan kata ago berarti aku membimbing. ${ }^{2}$ Dengan demikian, pendidikan secara etimologi selalu dihubungkan dengan kegiatan bimbingan terutama kepada anak, karena anaklah yang menjadi obyek didik.

Dalam bahasa Arab ditemukan penyebutannya ada tiga kata, yakni at-tarbiyah, al-ta'lim dan alta'dỉ yang secara etimologi yang kesemuanya bisa berarti bimbingan dan pengarahan. Namun demikian para pakar pendidikan cenderung berbeda dalam hal penggunaan ketiga kata tersebut. ${ }^{3}$

Berkaitan dengan itu, maka penulis memahami bahwa kata $t a^{\prime} d i b$ lebih mengacu pada pendidikan moralitas (adab) dan kata ta'lim lebih mengacu pada aspek intelektual (pengetahuan) dan tarbiyah lebih mengacu pada pengertian bimbingan, pemeliharaan, arahan, penjagaan dan pembentukan kepribadian. Karena itu term yang terakhir ini, kelihatannya lebih menunjuk pada arti yang lebih luas. ${ }^{4}$ 
Salat

Salat merupakan rukun Islam setelah ikrar dua kalimat syahadat. Dalam ajaran Islam, salat ibadah yang paling awal di syariatkan, mempunyai kedudukan paling penting dari lima rukun Islam yang ada. Selain itu, salat juga merupakan satu-satunya ibadah yang yang paling banyak disebutkan dalam Alquran. Selain sebagai sarana untuk bermunajat (berdialog) dengan Allah, salat juga bertujuan utamanya untuk ber-dzikrullah, itu juga berfungsi bagai pengendali diri pencegah dari perilaku keji (fakhsya') dan mungkar.

Sebagaimana hadis yang berkaitan dengan salat:

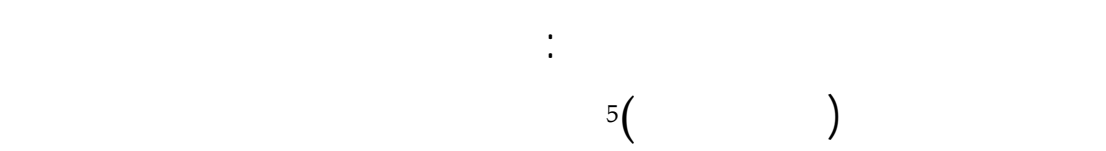

Salatlah kalian seperti kalian melihat aku salat (HR Bukhori)

\section{Takhrij Hadis}

\section{Metode yang Digunakan dan Teknik Analisis}

Menurut Abdul Hadi, ada lima macam metode تخريج الحديث: 1). takhrij menurut lafaz pertama hadis, 2). takhrij menurut lafaz yang ada pada matan hadis, 3) takhrij menurut klasifikasi hadis dan jenis hadis, 4). takhrij menurut periwayat terakhir, 5) takhrij menurut tema hadis. ${ }^{6}$ Sedangkan M. Syuhudi menyebutkan dua metode takhrij yaitu: 1) takhrij bi al-Fadz yakni penelusuran hadis Nabi berdasarkan petunjuk lafaz yang ada pada hadis, 2) takhrij bi al-Maudu' yaitu penelusuran hadis Nabi berdasarkan tema atau topik masalah yang berhubungan dengan hadis yang diteliti. ${ }^{7}$

Dari beberapa metode di atas, penulis menilai bahwa apa yang dikemukakan M. Syuhudi Ismail lebih praktis dan lebih mudah diaplikasikan. Oleh karena itu, penulis memilih metode yang digunakan dalam mentakhrij hadis adalah penelusuran hadis Nabi berdasarkan lafaz atau suku kata dari matan hadis dengan menggunakan kamus petunjuk yakni kitab al-Mu'jam Mufahras li Alfadz al-Hadīs al-Nabawi, yang merujuk pada 9 kitab hadis (kutub tis'ah), karangan Arnold J. Wensink.

Adapaun lafaz-lafaz yang dijadikan dalalah dalam penelusuran hadis yang sesuai dengan petunjuk kitab al-Mu'jam al-Mufahras li Alfadz al-Hadis al-Nabawi, adalah: lafaz dan يؤدب mengingat waktu yang sangat singkat untuk meneliti hadis secara sempurna.

Berdasarkan isyarat dari lafaz di atas, menunjukkan bahwa hadishadis mengenai pendidikan dan salat dapat ditemukan dalam beberapa kitab-kitab hadis yang menjadi sumber primer, lalu kemudian diklasifikasikan berdasarkan masalah dan keragaman riwayat dari beberapa mukharrij. 
Adapun metode yang digunakan adalah metode maudhui'iy dengan jalan mengidentifikasi hadis-hadis yang berhubungan dengan aspek-aspek pendidikan dalam salat sebagai tema sentral kajian berdasarkan sub-sub hadis yang menjadi sub pembahasan sibagaimana telah diuraikan pada rumasan masalah di atas.

\section{Klasifikasi}

Berdasarkan petunjuk takhrij dari beberapa kitab tersebut di atas, maka penulis menampilkan teks-teks hadisnya dalam dua klaisifikasi berdasarkan sub-sub yang dipilih, sebagai berikut:

\section{HADIS TENTANG KONSEP FITRAH DALAM DUNIA PENDIDIKAN}

Pada klasifikasi pertama ini, ditemukan hadis-hadisnya pada kitab:

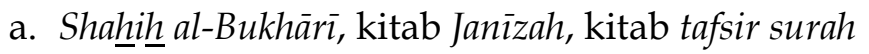

b. Shahih Muslim ditemukan pada kitab al-Qadr

c. Sunan al-Tumūziy, kitab al-Qadr an Rasulillah Saw.

d. Sunan Abu Daūd, kitab as-Sunnah.

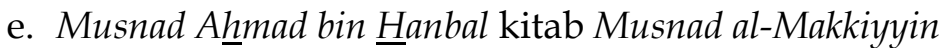

f. Muwaththa Malik, kitab al-Janā'iz

Adapun tampilan teks-teks hadisnya, sebagai berikut:

- Shahih al-Bukhārī, kitab Janīzah, kitab tafsir surah

•

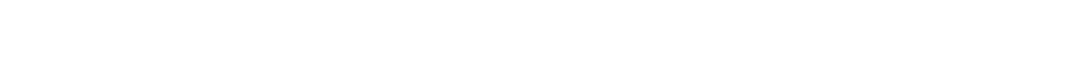

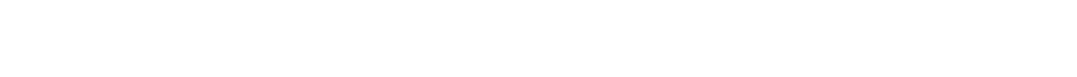
醇 国

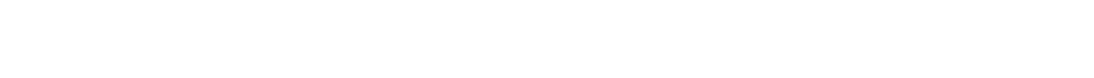

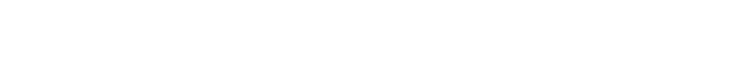

- Shahhㅡ Muslim ditemukan pada kitab al-Qadr

•

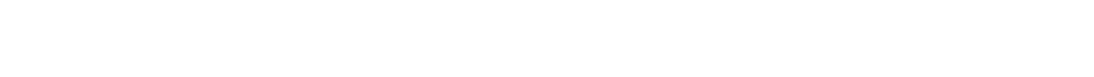

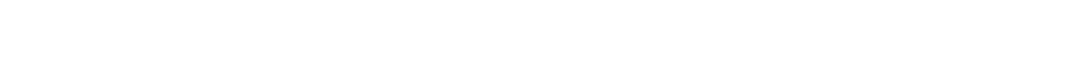

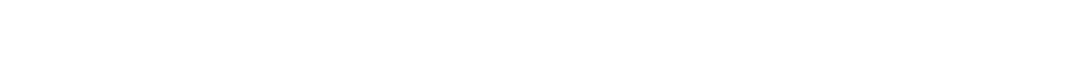




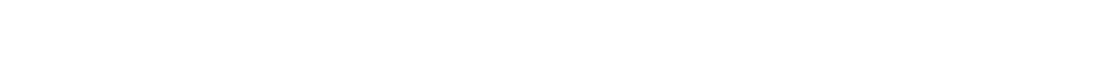

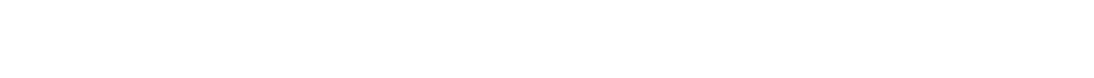

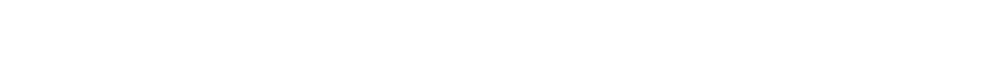

- Sunan al-Tumūziy, kitab al-Qadr an Rasulillah Saw.

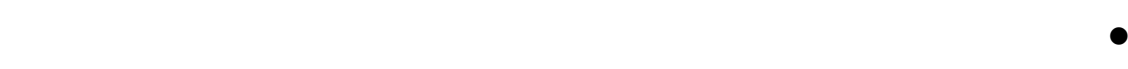
U5

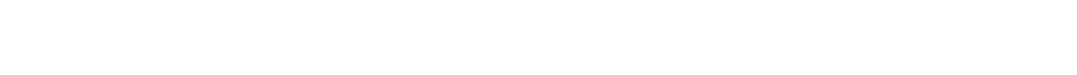
国 国 然

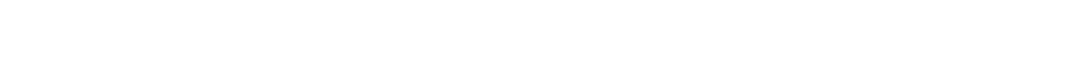

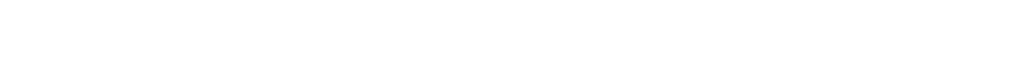

- Sunan Abu Daūd

• •

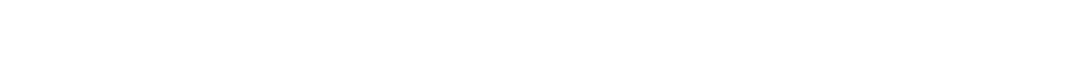

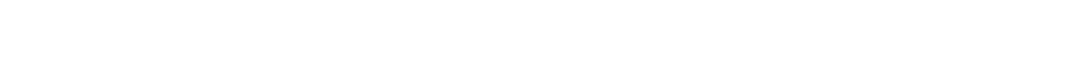

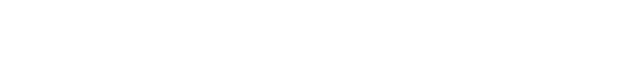

- A $\underline{h m a d}$

过和国

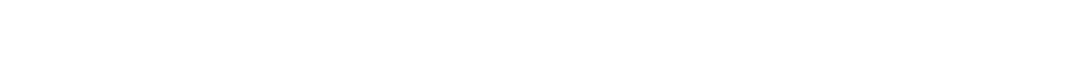

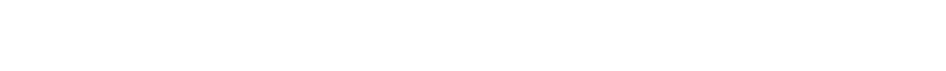

- Muwaththa Malik

و 国

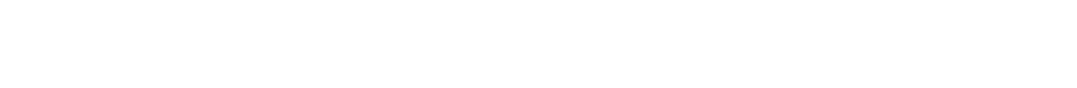
口 
HADIS TENTANG PENDIDIKAN SALAT BAGI ANAK SEJAK UMUR TUJUH TAHUN

Pada klasifikasi kedua ini, ditemukan hadis-hadisnya pada kitab:

a. Sunan al-Tumūziy, kitab as-shalāta, bab ma ja'a matā yu'maru ash-shabiyya ash-shalāta.

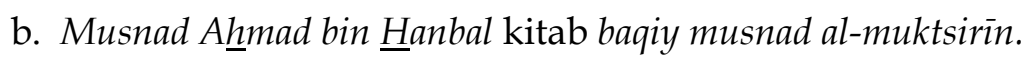

c. Sunan ad-Darimiy, kitab ash-shalāh bab mataa yu'maru ash-shabiyya ashshalāta.

Adapun tampilan teks-teks hadisnya, sebagai berikut:

- Sunan al-Tumūziy, kitab as-shalāta, bab ma ja'a matā yu'maru ashshabiyya ash-shalāta.

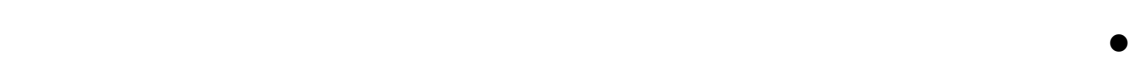

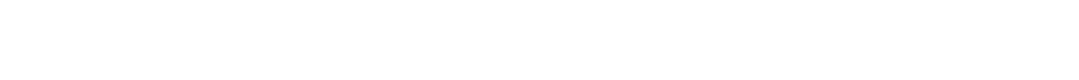

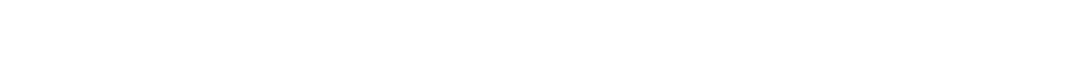

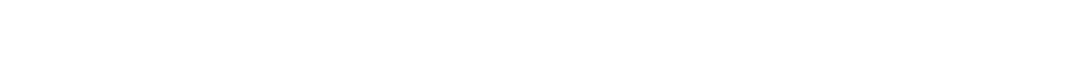

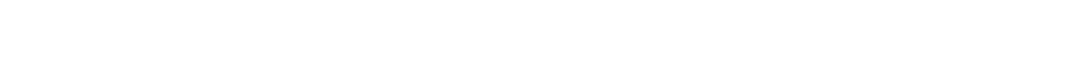

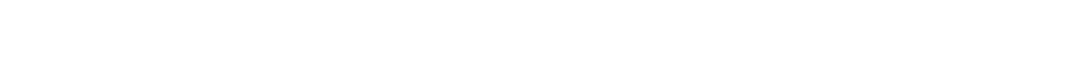

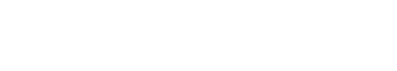

- Musnad Ahmad bin $\underline{H a n b a l ~ k i t a b ~ b a q i y ~ m u s n a d ~ a l-m u k t s i r i n ~}$

界

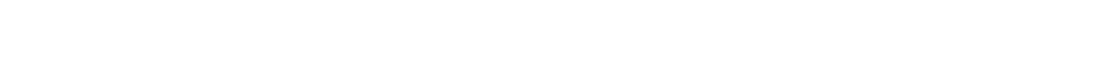

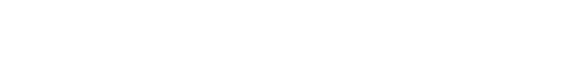

- Sunan ad-Darimiy, kitab ash-shalāh bab matā yu'maru ash-shabiyya ash-shalāta.

•

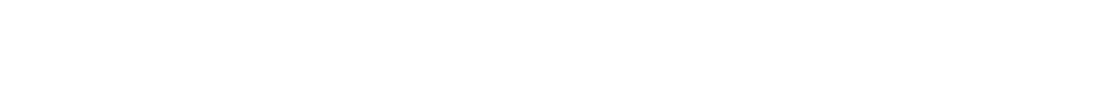

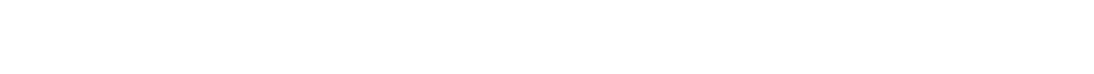

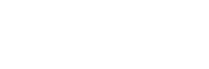




\section{Syarah hadis/sub-sub yang dipilih}

\section{Syarah Hadis tentang Konsep Fitrah dalam Dunia Penddikan

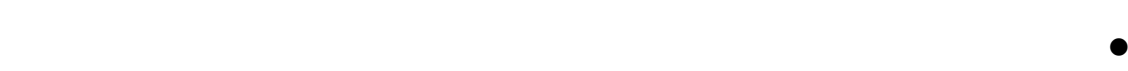

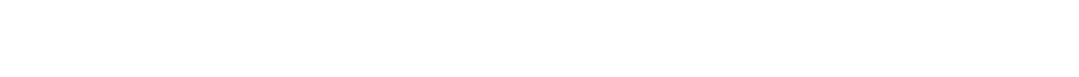 ....}

... tidak seorang pun anak yang dilahirkan kecuali dilahirkan dalam keadaan suci (fitrah) orang tuanyalah yang akan menentukan (mendidiknya) menjadi Yahudi, Nasgraniy, dan Majuziy.

Walaupun hadis di atas, tidak mengunakan kata tarbiyah, ta'lim atau $t a^{\prime} d i b$, namun hadis tersebut seringkali ditemukan dalam buku-buku pendidikan Islam. Teks hadis tersebut relevan dengan QS. al-Rum (30): 30 yang menggunakan kata fitrathallahi (فطرة الهد), sebagai berikut:

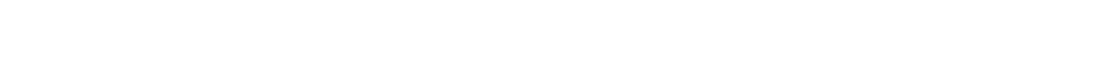

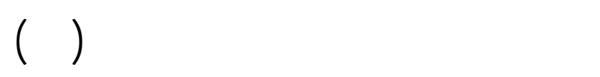

Maka hadapkanlah wajahmu dengan lurus kepada agama Allah; (tetaplah atas) fitrah Allah yang Telah menciptakan manusia menurut fitrah itu. tidak ada peubahan pada fitrah Allah. (Itulah) agama yang lurus; tetapi kebanyakan manusia tidak mengetahui. ${ }^{9}$

Ayat tersebut mengandung interpretasi bahwa manusia diciptakan Allah swt. mempunyai naluri beragama, yaitu agama tauhid. ${ }^{10}$ Potensi fitrah Allah swt. pada diri manusia ini selalu mencari indikator sebagai realitas mutlak (ultimate reality) dengan cara mengekspresikannya dalam bentuk sikap, cara berpikir dan bertingkah laku. Dengan sikap inilah sehingga manusia juga disebut sebagai homo educandum (makhluk yang dapat dididik) dan homo education (makhluk pendidik), karena pendidikan baginya adalah suatu keharusan guna mewujudkan kualitas dan integritas kepribadian yang utuh.

Di dalam fitrah mengandung pengertian baik-buruk, benar-salah, indah-jelek dan seterusnya. Pelestarian fitrah ini ditempuh lewat pemeliharaan sejak awal (preventive) atau mengembangkan kebaikan setelah ia mengalami penyimpangan (kuratif). ${ }^{11}$

Pada sisi lain, tentu saja fitrah atau dalam hal ini sikap keberagamaan yang dibawa oleh setiap manusia sejak kecil. Pada perkembangannya akan mengalami tingkatan-tingkatan bervariasi, sesuai dinamika dan faktorfaktor yang mempengaruhinya. Faktor pertama yang mempengaruhi tingkat keberagamaan adalah pengaruh pendidikan dalam lingkungan keluarga, sebagai unit dan institusi pertama anak dipelihara dan dididik. 
Lingkungan keluarga memberikan peranan yang sangat berarti dalam proses pendidikan keberagamaan anak. Sebab di lingkungan inilah anak menerima sejumlah nilai dan norma yang ditanamkan sejak awal. Kaitannya dengan itu, Mapanganro mengatakan bahwa pada masa-masa tersebut keimanan anak belum merupakan keyakinan sebagai hasil pemikiran yang obyektif, tetapi lebih merupakan sebagian dari kehidupan alam perasaan yang berhubungan erat dengan kebutuhan jiwanya akan kasih sayang, rasa aman dan kenikmatan jasmaniah. Peribadatan anak pada masa ini masih merupakan tiruan dan kebiasaan yang kurang dihayati. ${ }^{12}$

\section{Syarah Hadis tentang Pendidikan Salat bagi Anak Sejak Umur Tujuh} Tahun

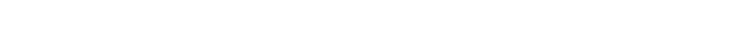

... Ajarkanlah ajarmu untuk salat sejak umur 7 tahun dan pukullah mereka (ketika meninggalkan salat) dalam umur sepuluh tahun...

Salat adalah tiang agama (الصلاة عم اد الـ ـنن), dan karena itulah, maka perintah untuk mendidik anak dilakukan sejak dini, yakni sejak anak berusia tujuh tahun (sab'ah sininah). Pendidikan salat dalam usia dini, lebih awal dimulai oleh usaha orang mendidik anaknya dalam bentuk hadhānah. Hal ini sering dengan fase perkembangan anak dan ketika ia memiliki potensi-potensi biologis, paedagogis, mulailah diperlukan adanya pembinaan, pelatihan, bimbingan, pengajaran dan pendidikan yang disebut alhadhānah.

Hadhānah merupakan hak bagi anak-anak yang masih kecil, karena ia membutuhkan pengawasan, penjagaan, pelaksana urusannya dan orang yang mendidiknya. Pendidikan yang paling penting ialah pendidikan anak kecil dalam pangkuan ibu bapaknya. Karena dengan demikian pengawasan dan perlakuan mereka kepadanya secara baik akan dapat menumbuhkan jasmani dan akalnya, membersihkan jiwanya serta mempersiapkan diri anak menghadapi kehidupannya di masa datang. ${ }^{13}$

Pendidikan yang strategis pada anak sejak dini di lingkungan rumah tangga, merupakan sesuatu yang esensial dalam menjaga fitrahnya. Dalam lingkungan itu pula anak telah memperoleh percikan sifat-sifat kesempurnaan Ilahi. ${ }^{14}$

Lebih lanjut tentang pentingnya pendidikan anak sejak kecil adalah

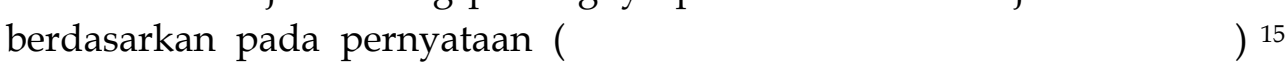
(Sesungguhnya pengajaran atau pendidikan di waktu kecil bagaikan mengukir di atas batu) ini berarti bahwa jika seseorang sejak kecilnya diajarkan dan ditanamkan sifat-sifat ketuhanan, maka sifat-sifat itu berbekas sampai masa dewasa dan sulit terhapus. 


\section{ANALISIS ASPEK-ASPEK PENDIDIKAN DALAM SALAT}

Salat merupakan rukun Islam setelah ikrar dua kalimat syahadat. Dalam ajaran islam, salat ibadah yang paling awal di syariatkan, mempunyai kedudukan paling penting dari lima rukun Islam yang ada. Hadis yang berkaitan dengan salat:

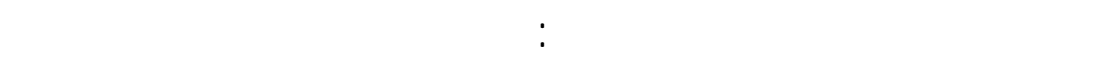

$$
\begin{aligned}
& \text { كما رايتمول لصلي (روه البخاري) } 16
\end{aligned}
$$

Sholatlah kalian seperti kalian melihat aku sholat

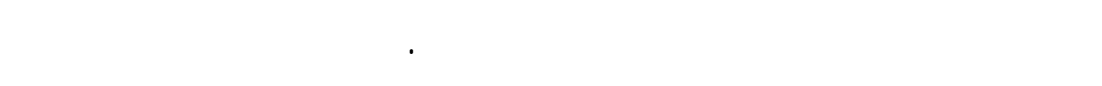

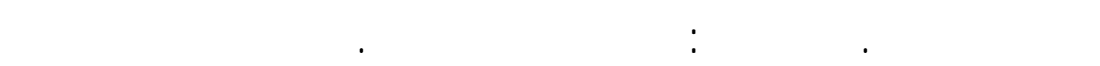

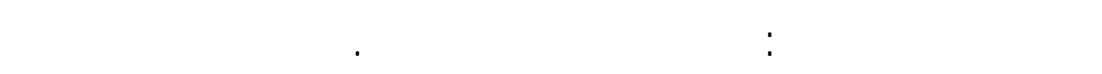

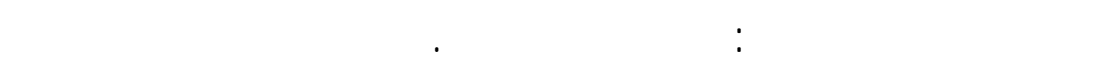

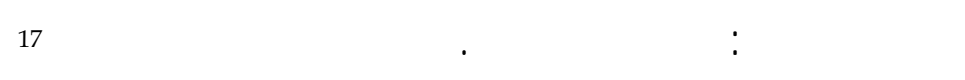

Sesungguhnya hal yang pertama kali diwajibkan oleh Allah kepada manusia dalam agama mereka adalah salat. Ia merupakan perintah terakhir yang ditetapkan Allah. Dan amal pertama ynag akan dihisab oleh Allah juga salat. Allah berfirman: Lihatlah (wahai malaikat) salat hamba-Ku. Jika salatnya sempurna, maka catatlah salatnya dengan sempurna. Sebaliknya jika salatnya kurang sempurna, maka Allah akan berfirman: Lihatlah (wahai malaikat), apakah dia kerjakan salat sunnah. Jika ditemukan salat sunnah padanya maka sempurnalah salat wajib itu baginya karena ia melakukan salat sunnah. Selanjutnya firman Allah: Lihatlah, apakah zakatnya sempurna. Jika zakatnya sempurna maka tulislah sempurna, namun jika zakat itu kurang maka Allah berfirman: lihatlah apakah ia bersedekah. Jika ia suka bersedekah maka sempurnalah zakat baginya"

Hadis ini sebagaimana dijelaskan dalam kitab at-targhīb wa-tarhì karya al-Munziri tentang salat, bab menjaga lima waktu yang di kutip oleh Abu Sankan.

\section{Aspek Pendidikan Akhlak dan Kepedulian Sosial dalam Salat}

Berkenaan dengan ini, firman Allah yang banyak dikutip ialah:

Bacalah apa yang telah diwahyukan kepada engkau (hai Muhammad), yaitu Kitab Suci, dan tegakkanlah salat. Sesungguhnya salat itu mencegah dari yang kotor dan keji, dan sungguh ingat kepada Allah adalah sangat agung (pahalanya). Allah mengetahui apa yang kamu sekalian kerjakan. ${ }^{18}$

Dengan jelas firman itu menunjukkan bahwa salah satu yang dituju oleh adanya kewajiban salat ialah bahwa pelakunya menjadi tercegah dari kemungkinan berbuat jahat dan keji. Maka pencegahan diri dan perlin- 
dungannya dari kejahatan dan kekejian itu merupakan hasil pendidikan melalui salat. Jika salat tidak mencapai hal demikian, maka merupakan kegagalan yang justru terkutuk dalam pandangan Allah, firman Allah:

Sudahkah engkau lihat orang yang mendustakan agama? Yaitu dia yang menghardik anak yatim, dan tidak dengan tegas menganjurkan pemberian makan kepada orang miskin! Maka celakalah untuk mereka yang salat, yang lupa akan salat mereka sendiri. Yaitu mereka yang suka pamrih, lagi enggan memberi pertolongan. ${ }^{19}$

Jadi, ditegaskan bahwa salat seharusnya menghasilkan rasa kemanusiaan dan kesetiakawanan sosial, yang dalam firman itu dicontohkan dalam sikap penuh santun kepada anak yatim dan kesungguhan dalam memperjuangkan nasib orang miskin.

Dalam kaitannya dengan firman itu Muhammad Mahmud al-Shawwaf menguraikan makna ibadat demikian: Terdapat berbagai bentuk ibadat pada setiap agama, yang diberlakukan untuk mengingatkan manusia akan keinsyafan tentang kekuasaan Ilahi yang Maha Agung, yang merupakan sukma ibadat itu dan menjadi hikmah rahasianya sehingga seorang manusia tidak mengangkangi manusia yang lain, tidak berlaku sewenangwenang dan tidak yang satu menyerang yang lain. Sebab semuanya adalah hamba Allah. Betapapun hebat dan mulianya seseorang namun Allah lebih hebat, lebih mulia, lebih agung dan lebih tinggi. Jadi, karena manusia lalai terhadap makna-makna yang luhur ini maka diadakanlah ibadat untuk mengingatkan mereka. Oleh karena itulah setiap ibadat yang benar tentu mempunyai dampak dalam pembentukan akhlak pelakunya dan dalam pendidikan jiwanya. ${ }^{20}$

Salat adalah ibadat yang paling agung, dan suatu kewajiban yang ditetapkan atas setiap orang muslim. Allah memerintahkan untuk menegakkannya, tidak sekedar menjalaninya saja. Dampak salat dan hasil tujuannya ialah sesuatu yang diberitakan Allah kepada kita dengan firman-Nya:

Sesungguhnya salat mencegah dari yang kotor dan keji", 21 dan firman-Nya lagi, "Sesungguhnya manusia diciptakan gelisah: jika keburukan menimpanya, ia banyak keluh kesah; dan jika kebaikan menimpanya, ia banyak mencegah (dari sedekah). Kecuali mereka yang salat... 22

Allah memberi peringatan keras kepada mereka yang menjalani salat hanya dalam bentuknya saja seperti gerakan dan bacaan tertentu namun melupakan makna ibadat itu dan hikmah rahasianya, yang semestinya menghantarkannya pada tujuan mulia berupa gladi kepribadian, pendidikan kejiwaan dan peningkatan budi.

Allah berfirman:

Maka celakalah untuk mereka yang salat, yang lupa akan salat mereka sendiri. Yaitu mereka yang suka pamrih, lagi enggan memberi pertolongan. ${ }^{23}$ 
Mereka itu dinamakan "orang yang salat" karena mereka mengerjakan bentuk lahir salat itu, dan digambarkan sebagai lupa akan salat yang hakiki, karena jauh dari pemusatan jiwa yang jernih dan bersih kepada Allah Yang Maha Tinggi dan Maha Agung.

Para ulama membagi riya atau pamrih menjadi dua. Pertama, pamrih kemunafikan, yaitu jika perbuatan ditujukan untuk dapat dilihat orang lain guna mendapatkan pujian, penghargaan atau persetujuan mereka. Kedua pamrih adat kebiasaan, yaitu perbuatan dengan mengikuti ketentuan-ketentuannya namun tanpa memperhatikan makna perbuatan itu dan hikmah rahasianya serta faedahnya, dan tanpa perhatian kepada Siapa (Tuhan) yang sebenarnya ia berbuat untuk-Nya dan guna mendekat kepadaNya. Inilah yang paling banyak dikerjakan orang sekarang. Sungguh amat disayangkan. ${ }^{24}$

\section{Efek Konstruktif dan Psikologis Salat dalam Makna Intrinsik dan Instrumental}

Berdasarkan berbagai keterangan dalam Alquran dan Hadis Nabi, dapatlah dikatakan bahwa salat adalah kewajiban peribadatan (formal) yang paling penting dalam sistem keagamaan Islam. Kitab Suci banyak memuat perintah agar kita menegakkan salat (iqāmat al-shalāh, yakni menjalankannya dengan penuh kesungguhan), dan menggambarkan bahwa kebahagiaan kaum beriman adalah pertama-tama karena salatnya yang dilakukan dengan penuh kekhusyukan. ${ }^{25}$

Sebuah hadis Nabi saw. menegaskan:

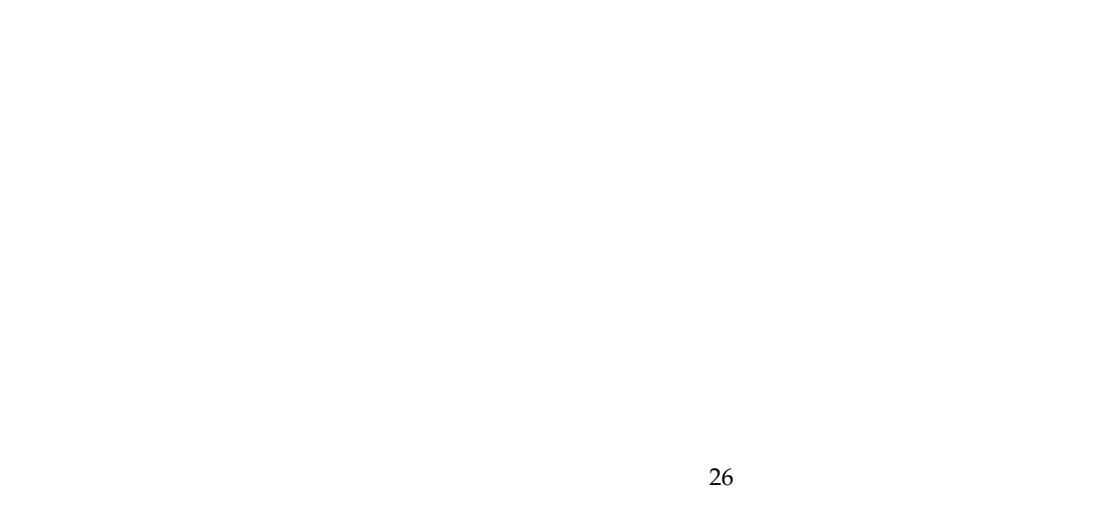

." Yang pertama kali akan diperhitungkan tentang seorang hamba pada hari Kiamat ialah salat: jika baik, maka baik pulalah seluruh amalnya; dan jika rusak, maka rusak pulalah seluruh amalnya..."

Sabda beliau lagi, "Pangkal segala perkara ialah al-Islam (sikap pasrah kepada Allah), tiang penyangganya salat, dan puncak tertingginya ialah perjuangan di jalan Allah." 27 
Salat disebut bermakna intrinsik (makna dalam dirinya sendiri), karena ia merupakan tujuan pada dirinya sendiri, khususnya salat sebagai peristiwa menghadap Allah dan berkomunikasi dengan Dia, baik melalui bacaan, maupun melalui tingkah laku (khususnya ruku' dan sujud). Salat disebut bermakna instrumental, karena ia dapat dipandang sebagai sarana untuk mencapai sesuatu di luar dirinya sendiri.

Demikian penjelasan seorang ahli agama dari Arab, al-Shawwaf, tentang makna instrumental salat. Dalam Kitab Suci juga dapat kita temukan ilustrasi yang tajam tentang keterkaitan antara salat dan perilaku kemanusiaan:

\section{Peranan dan Hikmah Bentuk Ritual Salat dalam Mencegah Kemaksiatan dan Kejahatan}

$A f^{\prime} a \bar{l}$ atau sikap dan gerak gerik kita dalam salat mengandung hikmah yang sangat efektif untuk mencegah kemaksiatan dan kejahatan, sebagaimana uraian berikut:

a. Waktu salat kita dituntut untuk menutup aurat dengan sempurna, baik laki maupun wanita. Hikmah yang terkandung didalamnya adalah agar senantiasa menutupi aurat kemanapun kita pergi atau berhadapan dengan orang lain yang bukan muhrim atau bukan suami/isteri.

b. Selama salat, mata kita dilatih untuk hanya melihat tempat sujud, tidak boleh menoleh kiri kanan atau kebelakang. Ini melatih diri kita untuk selalu mengendalikan pandangan mata "Ghadhul bashär" karena mata yang liar adalah sumber kejahatan dan kemaksiatan.

c. Selama salat lidah kita hanya boleh membaca bacaan salat saja. Ini melatih diri kita untuk senantiasa hanya mengucapkan kata kata yang diridhai Allah saja, agar terjauh dari kata kata kotor, bohong, gunjing, gossip dan caci maki yang semunya akan membawa pada kejahatan dan kemaksiatan.

d. Selama salat, telinga juga tidak boleh mendengarkan apapun dengan sengaja selain bacaan salat kita sendiri atau bacaan imam. Ini melatih diri kita untuk hanya mendengarkan hal-hal yang diredhai Allah saja, menjauhkan pendengaran dari hal yang tidak diridhai Allah karena apa yang kita dengarkan akan mempengaruhi hati dan tingkah laku kita.

e. Kaki dan tangan kita selama salat dilatih tidak bergerak seenaknya, tidak melangkah kemanapun, dan tidak memegang atau menggerakkan tangan seenaknya, ini melatih kita agar kaki dan tangan kita juga hendaknya selalu melangkah dan melakukan hal-hal yang diridhai Allah saja. Tidak mempergunakannnya untuk kejahatan dan kemaksiatan apapun karena semuanya itu akan dipertangggungjawabkan di hadapan Allah kelak di akhirat. 
Demikianlah di antara hikmah bacaan dan sikap gerak gerik salat yang telah ditanamkan Rasulullah saw. pada para sahabat dan umat beliau sehingga salat mereka telah terbukti membentuk pribadi berakhlak mulia yang bersih dari segenap kemaksiatan dan kejahatan.

\section{Manfaat Salat Ditinjau dari Aspek Kesehatan'28}

Untuk melakukan salat diwajibkan dalam keadaan berwudu, dan dianjurkan untuk memperbaharui wudunya. Setelah berwudu, dengan pakaian dan tempat yang bersih, salat dimulai dengan gerakan takbir dan diakhiri dengan salam. Manfaat salat ialah:

a. Kebersihan, pada waktu wudu terjadi pencucian permukaan tubuh yang pada umumnya terbuka dan mudah terkena debu yang sering mengandung bibit penyakit. Penelitian kimiawi membuktikan bahwa akan terjadi penurunan yang sangat besar kadar suatu zat jika dilakukan pembilasan minimal 3 kali.

b. Pendinginan, dinginnya air wudu menurunkan suhu permukaan tubuh, terutama kepala (ketika mengusap air ke kepala) yang didalamnya terdapat otak, organ yang aktivitasnya sangat tinggi (walaupun ukurannya relatif kecil) jika dibandingkan organ tubuh yang lain.

c. Stretching, peregangan otot untuk menghilangkan kekakuan otot sehingga kita menjadi lebih relaks, peregangan terjadi pada otot-otot: 1) Otot bahu yang tanpa disadari menjadi tegang jika kita berfikir. Peregangan terjadi ketika gerakan takbir dan ruku. 2) Otot punggung dan otot belakang tungkai, peregangan terjadi ketika ruku. 3) Otot paha depan dan otot betis, peregangan terjadi ketika duduk di antara dua sujud. Pada duduk ini selain peregangan otot betis juga dipijat, ditekan oleh paha. Catatan istirahat yang lebih baik setelah perjalanan jauh sebenarnya adalah lakukan seperti duduk di antara dua sujud untuk beberapa saat baru kemudian berbaring.

d. Pembilasan otak, ketika kita sujud, karena posisi jantung lebih tinggi dari kepala maka volume darah akan meningkat di dalam kepala. Hal ini berarti bertambahnya zat makanan yang masuk ke dalam otak dan bertambahnya juga sisa makanan yang keluar dari otak ketika kepala ditegakkan kembali.

e. Relaksasi, mata yang hanya tertuju pada sajadah dan napas yang teratur serta bacaan-bacaan salat membuat kita akan menjadi lebih relak, terlebih lagi dengan memahami makna bacaan salat akan menambah keyakinan kita kepada Allah yang maha pengasih, yang maha penyayang, serta yang mengabulkan doa orang-orang yang berdoa. Hal ini tentunya akan membuat kita menjadi lebih tenang lagi. 
Jika kita membandingkan ritme kehidupan harian dengan waktu salat, maka manfaat menyegarkan akan makin terasa. Kekakuan otot setelah diam dalam keadaan tidur dihilangkan dengan salat subuh. Kelelahan setelah aktivitas menjelang siang akan berubah menjadi lebih segar setelah salat duhur. Kemampuan tubuh yang semakin menurun setelah tengah hari disegarkan dengan dua salat fardu, salat ashar dan maghrib. Tubuh yang telah segar dan relaks setelah salat isya akan lebih mudah tertidur.

\section{Gerakan Salat Mengandung Energi ${ }^{29}$}

Kenapa salat harus 5 kali dalam sehari? Menurut pendapat ilmuwan Cina:

a. Ada energi api akan keluar pada waktu jam 12.00 siang sampai sore, untuk mengobati jantung dan ginjal itu.

b. Dalam gerakan salat ashar adalah siklus dari panas ke dingin mereka menyebutnya terapi kandungan kemi. Secara alamiah gerakan ashar itu ternyata memisahkan zat-zat kimia dalam tubuh kita

c. Ada energi air yang keluar pada waktu jam 6 sore setelah terbenamnya matahari yang mereka menyebutnya bahwa maghrib itu menterapi ginjal.

d. Gerakan isya yaitu setelah mega merah hilang, ini mereka menyebutnya sebagai terapi yang mengurangi kelebihan energi. Ada energi kayu yang keluar pada waktu jam 11 malam, dia yang menghancurkan racunracun yang ada dibadan kita, dan menurut ilmuwan Cina racun itu bakar kayu untuk membuang racun di otak.

e. Kemudian jam 02 pagi otak dibersihkan oleh energi kayu, dan selanjutnya Allah menyediakan dan mengisinya untuk salat tahajud pada waktu sepertiga malam. Ilmuwan di Jerman melakukan penelitian Prof. Dr. Sholeh seorang guru besar Universitas Airlangga, telah membuktikan bahwa tahajjud yang teratur dan disiplin akan mencegah kanker, stres dan inspeksi, jika orang melakukan dengan teratur memiliki emosi yang positif. Energi udara keluar pada jam 02

f. Jam 03 pagi energi logam yang menterapi kita.

g. Jam 06 pagi melakukan salat dhuha untuk menterapi pencernaan.

Menurut Rasulullah Saw. meletakkan pergelangan tangan kanan di atas pergelangan tangan kiri yang berarti tangan kiri dijepit oleh jari tangan kanan, menjepit pembuluh balik tangan kiri yang menyebabkan pembuluh tangan kanan mengembang selama imam membacakan alfatihah dan surah.

Di saat kita mau ruku tangan diangkat, semprotan dari tangan kanan itu langsung ke telinga ke mata dan sebahagian otak. Ruku meleturkan 
memori otak dan ginjal. Menurut para ilmuwan Cina, posisi sujud pembuluh jantung mengembang. Duduk pada tahiyat awal mereka mengatakan pembakaran mengefektifkan kelenjer keringat dan pencegahan pengapuran dan tahiyat akhir menterapi keseimbangan dan wasir. Duduk antara dua Sujud mereka menyebutnya duduk keperkasaan karena menarik syaraf dibawah lutut dan dipangkal paha.

Jadi kita tidak heran bahwa Allah menekankan gerakan salat dan waktu salat, ini merupakan syariah yang menerapi kita dan harus diperhatikan dan itulah makna ash-sholatu'imanuddin, salat merupakan tiang agama.

\section{Pengaruh Salat pada Kesehatan Tubuh Manusia}

Tidak diragukan bahwa di dalam salat terdapat unsur-unsur: menjaga kesehatan badan, menghancurkan sisa-sisa kotoran badan dan disamping manfaat intinya yaitu menjaga keimanan serta memperoleh kebahagiaan dunia akhirat. ${ }^{30}$ Antara lain pengaruhnya adalah:

a. Gerakan sujud dan kesehatan

Sujud merupakan gerakan yang manfaatnya meliputi banyak pergerakan tubuh, membengkokkan kedua lutut bermanfaat mencegah terjadinya kejang (kaku) pada kedua lutut. Membengkokkan badan ke depan dan meletakkan dahi pada tanah merupakan kegiatan yang paling bermanfaat dalam proses pemijatan terhadap perut dan perangkat pencernaan sehingga membantu proses pencernaan. Sujud dapat mencegah peningkatan bahan-bahan minyak dan kegemukan, disamping juga memerkuat otot perut. Sujud juga membantu mencegah pengerutan serat pengendoranpengendoran tertentu pada perut. Sujud juga mampu mengaktifkan (melancarkan) aliran darah pada paru-paru dan kepala. ${ }^{31}$

b. al-Qiyam (berdiri)

Setelah takbiratul ihram (takbir diawal salat), berdiri merupakan gerakan pertama dalam salat. Pada posisi berdiri ini otot yang berada di punggung memberikan kesempatan kepada tulang punggung pada posisi lurus.

Salat dianggap sebagai pencegah penyakit varises, melalui tiga faktor, sebagai berikut:

1) Gerakan-gerakan salat yang khas dan istimewa mampu memperkecil tekanan pada dinding-dinding yang lemah bagi urat-urat kaki bagian luar.

2) Salat mengaktifkan kerja pemompaan urat-urat bagian samping sehingga meringankan tekanan pada urat-urat bagian samping. 
3) Memperkuat dinding-dinding urat yang lemah melalui peningkatan kemampuan zat-zat makanan pembangun tubuh dalam kaitanya dengan pembentukan organ-organ seluruh tubuh oleh zat makanan.

c. Gerakan ruku'

Posisi ruku' menempatkan jantung berada dalam satu garis horisontal dengan pembuluh darah tulang (besar, posisi ruku' tersebut jelas memudahkan aliran darah untuk kembali ke jantung karena pengaruh aktivitas penarikan oleh pengerutan dinding perut. Akhirnya darah dapat dibersihkan dari segala kotoran secara maksimal setelah mengalir kebagian tubuh.

\section{d. Al-I'tidal (bangun dari ruku')}

Bangun dari ruku' membantu nafas yang dalam kalau diikuti mengeluarkan nafas tersebut dari arah yang berlawanan dengan kuat. Menyebabkan aliran darah yang tengah berada pada kedua kaki mempunyai kesempatan leluasa untuk berjalan cepat menuju rongga perut dimana urat-urat yang sedang lunak siap menerima darah yang tengah berjalan dari arah kaki. Aliran darah yang berasal dari kedua kaki yang menuju ke atas melewati dua tingkatan secara beruntun. Pertama pada saat mengeluarkan nafas dengan kuat darah berpindah dengan cepat dari urat-urat kaki menuju urat-urat perut. Kedua, ketika memulai mengambil nafas yang dalam, darah yang teerkumpul pada otot perut menepati jalan yang mudah menuju ke atas yang kemudian berada disisi kanan jantung untuk mencegah jatuhya darah kebawah sumbatan yang dipersiapkan utuk menerima darah dari urat-urat kedua kaki kembali. ${ }^{32}$

\section{Salat Tahajjud}

Dalam sebuah hadis, Rasullullah Saw. bersabda bahwa:

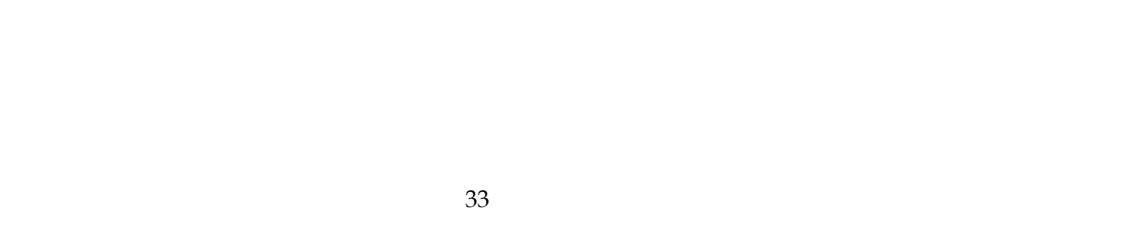

"Salat sunah yang utama setelah salat fardhu adalah salat Tahajud"

Dalam Alquran, Allah Swt. juga berfirman :

Dan pada sebagian malam hari, bersembahyang Tahajudlah kamu sebagai suatu ibadah tambahan bagimu: mudah-mudahan Tuhan-Mu mengangkat kamu ke tempat yang terpuji," 34

Ditinjau dari aspek religi, orang yang senantiasa melaksanakan salat Tahajud akan mendapatkan rasa kedekatannya kepada Allah Swt. Selanjutnya, dia akan merasakan ketentraman batin, dan mendapatkan keseimbangan kehidupan lahir dan bathin. 
Dari aspek kesehatan, salat Tahajud dapat membantu kita menyembuhkan penyakit yang kita derita. sebagaimana sabda Rasullulloh Saw. dalam sebuah hadis: "Salat Tahajud dapat menghapus dosa, mendatangkan ketenangan dan menghindarkan dari penyakit," (HR. Tirmidzi).

Dalam sebuah bukunya, Prof. Dr. Mohammad Soleh, setelah melakukan penelitian terhadap beberapa pelaku salat tahajud secara rutin dan ikhlas, mengungkapkan bahwa salat Tahajud memberi pengaruh terhadap peningkatan respons ketahanan tubuh imunologik.

Penelitian tersebut dilandasi oleh apa yang dianjurkan Alquran kepada kita untuk Iqra (bacalah), Wasma'u (simaklah), Afalaa tatafakkaruun (pikirkanlah), Afala tubshiruun (perhatikanlah), Afalaa tandhuruun (telitilah/risetlah), dan Afala tatadabbaruun (ungkapkanlah).

Oleh sebab itu, apabila kita menginginkan keseimbangan hidup sekaligus mendapatkan kesehatan jasmani dan rohani, salat Tahajud adalah (salah satu) jalan mujarab untuk mendapatkannya.

Dengan dosis 13 raka' at dalam waktu 8 minggu, salat Tahajud dapat menurunkan kadar kortisol. Pada kadar tinggi, kortisol bersifat imunosupresif. Sebaliknya dalam kadar rendah kortisol dapat mempengaruhi proliferasi limfosit. Dalam perspektif psikoneuroimunologi, terjadinya peningkatan respon imun ini akan meningkatkan ketahanan tubuh. Dengan kata lain, melalui turunnya kadar kortisol, para pengamal salat tahajud terhindar dari kemungkinan gejala stres. Keadaan terbebas dari stress akan membantu kita terhindar dari sakit atau penyakit. ${ }^{35}$

Demikianlah secuil makna, manfaat dan hikmah yang dapat disajikan oleh penulis, walaupun disadari bahwa hikmah dibalik salat tidak dapat dijangkau oleh manusia untuk menyingkap hikmah yang terkandung dalam salat secara sempurna, yang jelas bahwa salat adalah minia-tur dari kehidupan dunia dengan mengajarkan segala aspek kebaikan dalam kehidupan manusia termasuk aspek pendidikan.

\section{SIMPULAN}

Setelah menguraikan beberapa hal mengenai persoalan pendidikan yakni aspek-aspek pendidikan dalam salat, maka penulis akan menarik beberapa kesimpulan, sebagai berikut:

1. Hadis-hadis tentang pendidikan cukup banyak yang terdapat dalam kutb al-tis'ah.

2. Bahwa pendidikan sangat penting bagi manusia. Pendidikan yang dimaksud adalah tarbiyah, yakni proses pembentukan individu berdasarkan ajaran-ajaran Islam. Melalui proses pendidikan, individu dibentuk agar dapat mencapai derajat yang tinggi dan sempurna (insan kamil). Potensi secara alamiah (fitrah) yang dimiliki manusia memungkinkan 
manusia menerima pendidikan dari sejak umur dini, termasuk pendidikan salat sebagaimana hadis Nabi.

3. Aspek-aspek Pendidikan dalam Salat memiliki multi perspektif seperti pendidikan akhlak, intelektual dan kesehatan dan banyak lagi hikmahhikmah lain yang pada substansinya bermuara pada pembentukan kepribadian dan kebijaksanaan berperilaku sehingga bermanfaat terhadap pelakunya sendiri maupun kepada orang lain, ekonomi maupun sosial.

\section{CATATAN AKHIR}

1. Departemen Pendidikan dan Kebudayaan, Kamus Besar Bahasa Indonesia, Edisi III, cet. II, Jakarta: Balai Pustaka, 2002, h. 263.

2. Abu Ahmadi, Ilmu Pendidikan, cet. I, Jakarta: Balai Pustaka, 2002, h. 69.

3. Kata tarbiyah digunakan oleh Abd Rahman al-Nahlaw, kata ta'lim digunakan oleh Abd al-Fattah Jalal dan kata $t a^{\prime} d i b$ digunakan oleh Naquib al-Attas.

4. Muhammad Athiyah al-Abrasy, Ruh al-Tarbiyah wa al-Ta'lim, t.t Isa al-Babi alHalab, t.th, h. 14.

5. Hadis ini sebagaimana dijelaskan dalam kitab at-Targhib wa Tarhib karya alMunziri tentang salat bab menjaga lima waktu, h. 519.

6. Abu Muhammad Abd al-Hadi bin Add Qadir, Thuruq Takhrij Hadis Rasulullah Saw., diterjemahkan oleh S. Aqil Husain Munawwar dan H. Ahmad Rifqi Muchtar dengan judul Metode Takhrij al-Hadīs, cet. I, Semarang: Dina Utama, 1994, h. 15. Lihat juga Mahmud al-Tahhan Usul al-Takhrij wa Dirāsah al-Asanìd diterjemahkan oleh Ridwan Nasir dengan Judul Metode Takhrij dan Penelitian Hadis, Surabaya: Bina Ilmu, 1995, h. 5.

7. Lihat M. Syuhudi Ismail, Metodologi Penelitian Hadis Nabi, cet. I, Jakarta: Bulan Bintang, 1988, h. 46. Lihat juga Abuddin Nata, Metodologi Studi Islam, cet. IV, Jakarta: PT. Raja Grafindo Persada, 2002, h. 28-41.

8. Lihat A. J. Wensick. Concordance et Indices de la tradition Musulmane, diterjemahkan oleh Muhammad Fu'ad Abd al-Baqiy dengan judul al-Mu'jam alMufahras li Alfaz al-Hadis al-Nabawiy, Juz I, Leiden: E. J. Brill, 1936 M., h. 109.

9. Fitrah Allah: maksudnya ciptaan Allah. Manusia diciptakan Allah mempunyai naluri beragama yaitu agama tauhid.

10. Lihat interpretasi yang dikemukakan oleh al-Raghib al-Asfahani, Mufradat AFāz Al-qurān, cet. I, Beirut: Dār al-Syamiyah, 1992, h. 640.

11. Lihat Mudhar Ahmad, Manusia dan Kebenaran, Surabaya: Usaha Nasional, 1989, h. 31-32.

12. Mappanganro, Masa Kanak-kanak dan Perkembangan Rasa Keagamaan dalam "Warta Alauddin" XII No. 66, Ujung Pandang: IAIN Alauddin 1993, h. 16.

13. Syaid Sabiq, Fikh al-Sunnah diterjemahkan oleh Muhammad Tahalib dengan judul Fikh Sunnah, Jilid VIII, cet. VII; Bandung: PT. Al-Ma'arif, 1990), h. 161-162.

14. Lihat lebih lanjut dalam Acmadi, Ideologi Pendidikan Islam, cet. I, Yogyakarta: Pustaka Pelajar, 2005, h. 44.

15. Lihat Ahmad Fu'ad al-Ahwaniy, al-Tarbiyah fi al-Islām (Mesir: Dar al-Ma'arif, t.th), h. 242. 
16. Abi Abdullah Bin Ismail al-Bukhari, Shahih hㅡ Bukhāri, Jilid 1, Dār Al Fikri, Beirut Libanon, 1993, h. 174.

17. Abu Sankan, Pelatihan Salat Khusyu', Jakarta: Baitul Ihsan, t.th, h. 519.

18. QS. al-An'am/6: 102-3.

19. QS. al-Ma'un/107:1

20. Muhammad Mahmud al-Shawwaf, 'Uddat al-Muslimīn, Jeddah: al-Dār alSu'udiyyah li al-Nasyr, 1388 H/1968 M., h. 53-54.

21. QS. al-Ankabut/29:45.

22. QS. al-Ma'arij/70:19-22.

23. QS. al-Ma'un/107:

24. Muhammad Mahmud al-Shawwaf, 'Uddat al-Muslimin., op. cit., h. 55-57.

25. QS.al-Mu'minun 23:1-2.

26. Imam at-Turmuzy, $C D$ Digital, Program Mausu'ah al-Hadis al-Syarif, Sunan atTumuzy, hadis ke 378. Lihat juga Muhammad Mahmud al-Shawwaf, Kitab Ta'lìm al-Shalāh., op. cit., , h. 9.

27. Ibid., hal. 13.

28. http://triagus.multiply.com/journal/item/355/Salat_dari_Perspektif_kesehatan

29. http:// mlaty.blogspot.com/2009/05/salat-kesehatan.html

30. Misa Abduh, Menjernihkan Batin Dengan Salat Khusyu', Yogyakarta: Mitra Pustaka, 2006, h. 35.

31. M. Amin, Tafsir Ahkām, Jakarta: Logos Wacana Ilmu, 1997, h, 29.

32. Hilmi Al Khufi, Menyingkap Rahasia Gerakan Gerakan Salat, Yogyakarta: Diva Press, 2007, h. 43.

33. Imam Ahmad bin Hanbal, CD Digitala, Program Mausu'ah al-Hadis al-Syarif, Musnad Ahmad bin Hanbal, hadis ke 8178.

34. QS. Al-Isra 17:79

35. http://majelismunajat.com/2009/11/dampak-salat-tahajud-bagi-kesehatan/

\section{DAFTAR PUSTAKA}

Al-Qur'an al-Karim

Abduh, Misa, Menjernihkan Batin Dengan Salat Khusyu', Yogyakarta: Mitra Pustaka, 2006.

al-Abrasy, Muhammad Athiyah, Ruh al-Tarbiyah wa al-Ta'lim, t.t Isa al-Babi alHalab, t.th.

Ahmad, Mudhar, Manusia dan Kenbenaran, Surabaya: Usaha Nasional, 1989.

Ahmad, Mudhar, Ideologi Pendidikan Islam, Cet. I, Yokyakata: Pustaka Pelajar, 2005. Ahmadi, Abu, Ilmu Pendidikan, cet. I, Jakarta: Balai Pustaka, 2002.

al-Ahwaniy, Ahmad Fu'ad, al-Tarbiyah fi al-Islām, Mesir: Dār al-Ma'arif, t.th.

Amin, M., Tafsir Ahkām, Jakarta: Logos Wacana Ilmu, 1997.

al-Asfahani, al-Raghib, Mufradat al-Faz al-Qur'ān, cet. I, Beirut: Dār al-Syamiyah, 1992.

al-Bukhariy, Abu Abd Allah Muhammad Ibn Ismail Ibn Ibrahim Ibn Mughirah Ibn, CD-Room, Program Mausu'ah al-Hadīs al-Syarif li Kutub al-Tis'ah, Shahih al-Bukhāriy, kitab al-Ilm, hadis ke 1211. 
Departemen Pendidikan dan Kebudayaan, Kamus Besar Bahasa Indonesia, Edisi III, cet. II; Jakarta: Balai Pustaka, 2002.

Hanbal, Imam Ahmad bin, CD Digital, Program Mausu'ah al-Hadīs al-Syarîf, Musnad Ahmad bin Hanbal, hadis ke 8178.

Ismail, M. Syuhudi, Metodologi Penelitian Hadis Nabi, cet. I, Jakarta: Bulan Bintang, 1988.

al-Khufi, Hilmi, Menyingkap Rahasia Gerakan Gerakan Salat, Yogyakarta: Diva Press, 2007.

Mappanganro, Masa Kanak-kanak dan Perkembangan Rasa Keagamaan dalam "Warta Alauddin" XII No. 66, Ujung Pandang: IAIN Alauddin 1993.

Nata, Abuddin, Metodologi Studi Islam, cet. IV, Jakarta: PT. Raja Grafindo Persada, 2002.

Qadir, Abu Muhammad Abd al-Hadi bin Add, Thuruq Takhrïj Hadīs Rasulullah Saw. Ditejemahkan oleh S. Aqil Husain Munawwar dan H. Ahmad Rifqi Muchtar dengan judul Metode Takhrīj al-Hadīs, cet. I, Semarang: Dina Utama, 1994.

Sabiq, Syaid, Fikh al-Sunnah, diterjemahkan oleh Muhammad Tahalib dengan judul Fikh Sunnah, Jilid VIII, cet. VII; Bandung: PT. Al-Ma'arif, 1990.

Sankan, Abu, Pelatihan Salat Khusyu' Jakarta: Baitul Ihsan, t.th.

al-Shawwaf, Muhammad Mahmud, 'Uddat al-Muslimin Jeddah: al-Dar alSu'udiyyah li al-Nasyr, 1388 H/1968 M.

Suriosumantri, Jujun S., Falasafah Islam Sebuah Pengantar Populer, Jakarta: Sinar Harapan 1984.

Tafsir, Ahmad, Ilmu Pendidikan dalam Perspektif Islam, Bandung: Remaja Rosda Karya, 1994.

al-Tahhan, Mahmud. Usul al-Takhrij wa Dirasah al-Asanid diterjemahkan oleh Ridwan Nasir dengan Judul Metode Takhrij dan Penelitian Hadis Surabaya: Bina Ilmu, 1995.

al-Tumuziy, Abu Isa Muhammad Ibn Isa, CD-Room, Program Mausu'ah al-Hadis al-Syarif li Kutb al-Tis'ah, Sunan al-Turmuziy, kitab al-shalah hadis ke 272.

at-Turmuzy, CD Digital, Program Mausu'ah al-Hadis al-Syarif, Sunan at-Tumuzy, hadis ke 378.

Wensick, A. J. Concordance et Indices de la tradition Musulmane, diterjemahkan oleh Muhammad Fu'ad Abd al-Baqiy dengan judul al-Mu'jam al-Mufahras li Alfäz al-Hadīs al-Nabawiy, Juz I, Leiden: E. J. Brill, 1936 M.

http://triagus.multiply.com/journal/item/355/Salat_dari_Perspektif_kesehatan

http:// mlaty.blogspot.com/2009/05/salat-kesehatan.html

http:// majelismunajat.com/2009/11/dampak-salat-tahajud-bagi-kesehatan/ 